\title{
Flora da Paraíba, Brasil: Passifloraceae sensu stricto
}

\author{
Flora of Paraíba state, Brazil: Passifloraceae sensu stricto
}

\author{
Elainne Cristina Silva Costa ${ }^{1,4}$, Teonildes Sacramento Nunes ${ }^{2} \&$ José Iranildo Miranda de Melo $^{3}$
}

\begin{abstract}
Resumo
Este trabalho consiste no estudo taxonômico da família Passifloraceae para o Estado da Paraíba, Brasil. Foram registradas 11 espécies, todas pertencentes ao gênero Passiflora: P. alata, P. capsularis, $P$. cincinnata, $P$. edulis, $P$. foetida, P. glandulosa, P. misera, P. mucronata, $P$. silvestris, $P$. suberosa e $P$. watsoniana. Destas espécies, $P$. cincinnata e $P$. foetida são as mais amplamente distribuídas na Paraíba e $P$. capsularis foi referida pela primeira vez para a flora do Estado. São apresentadas descrições, chave para identificação, ilustrações, bem como comentários sobre período de floração e/ou frutificação, habitats e mapa de distribuição geográfica. Palavras-chave: Eudicotiledôneas, flora, taxonomia.
\end{abstract}

\begin{abstract}
This paper consists of the taxonomic study of the family Passifloraceae in the Paraíba state, Brazil. Eleven species were recorded, all belonging to the genus Passiflora: P. alata, P. capsularis, P. cincinnata, P. edulis, P. foetida, P. glandulosa, P. misera, P. mucronata, P. silvestris, $P$. suberosa and $P$. watsoniana. Of these species, $P$. cincinnata and $P$. foetida are the most widely distributed in Paraíba and $P$. capsularis is a new record for the flora of Paraíba state. We present descriptions, identification key, and illustrations, in addition to data on flowering and/or fruiting, habitats, and geographic distribution maps.
\end{abstract}

Key words: Eudicots, flora, taxonomy.

\section{Introdução}

Passifloraceae é uma família predominantemente tropical e subtropical, apresentando cerca de 650 espécies e 20 gêneros (Nunes \& Queiroz 2001, 2006). No Brasil, ocorrem quatro gêneros, Ancisthrothyrsus Harms, Dilkea Mast., Mitostemma Mast. e Passiflora L., com 144 espécies entre nativas e cultivadas (Nunes \& Queiroz 2006; Souza \& Lorenzi 2008; Bernacci et al. 2014). Segundo MacDougal \& Feuillet (2004), o gênero Passiflora reúne aproximadamente 525 espécies, destas apenas 22 espécies são nativas do sudeste da Ásia, Austrália e ilhas do Pacífico, apresentando-se como o mais diversificado taxonomicamente, inclusive na América do Sul. Passiflora destaca-se por possuir uma grande variedade de formas foliares, bem como uma considerável diversificação nos tipos de nectários extraflorais encontrados geralmente no caule, brácteas ou pecíolo (Krosnick \& Freudenstein 2005).

As obras mais relevantes sobre Passifloraceae datam desde o século XVIII, quando Linnaeus (1753), no Species Plantarum, reconhece 24 espécies para o gênero Passiflora. Posteriormente, Masters $(1871,1872)$ publica duas obras consecutivas ressaltando os aspectos históricos e a morfologia detalhada da família. De Candolle (1891) reconhece 126 espécies para o gênero Passiflora, alocando-as em secções. Outras importantes contribuições para a taxonomia de Passifloraceae foram oferecidas por Killip (1938), considerada uma das obras mais completas dentre as já publicadas para a família, seguida de Escobar (1988) e Cervi (1997), todas de fundamental importância para o entendimento sobre a taxonomia da família.

\footnotetext{
${ }^{1}$ Universidade Estadual da Paraíba, Campus I, 58429-500, Campina Grande, PB, Brasil.

${ }^{2}$ Universidade Estadual de Feira de Santana, Depto. Ciências Biológicas, 44036-900, Feira de Santana, BA, Brasil.

${ }^{3}$ Universidade Estadual da Paraíba, Centro de Ciências Biológicas e da Saúde, Depto. Biologia, 58429-500, Campina Grande, PB, Brasil.

${ }^{4}$ Autor para correspondência: elainne_bio@yahoo.com.br
} 
As espécies de Passiflora são popularmente conhecidas como maracujá e este gênero é bastante representado economicamente, estendendo-se por todos os Estados brasileiros. Algumas de suas espécies são utilizadas para fins medicinais e comercializadas devido às suas propriedades calmantes, antiespasmódicas, anti-helmínticas e até mesmo como reguladores de transtornos menstruais (Killip 1938; Chitty 2006), além de serem cultivadas para fins ornamentais por apresentarem flores coloridas e perfumadas (Bernacci et al. 2003).

Apesar da sua expressiva representatividade na flora do Brasil, esta família é ainda pouco estudada do ponto de vista taxonômico no país, principalmente na região Nordeste. O presente trabalho teve por objetivo principal executar o estudo taxonômico da família Passifloraceae sensu stricto no estado da Paraíba visando conhecer a riqueza e a distribuição da família na flora deste Estado.

\section{Material e Métodos}

O estado da Paraíba é um dos menores do Nordeste do Brasil, possuindo uma extensão territorial de $56.469 \mathrm{~km}^{2}$ e 223 municípios (Moreira et al. 1985). Segundo o mesmo autor, o estado apresenta uma notável variação da paisagem natural, onde áreas úmidas contrapõemse às semiáridas, alguns rios secam durante longos períodos de estiagem enquanto outros são perenes, permanecendo cheios durante todo ano. A vegetação da Paraíba reflete condições ambientais diferenciadas em seus diversos compartimentos geomorfológicos, apresentando diferentes formações vegetacionais, das quais se podem destacar: campos e matas de restinga, as quais se desenvolvem especialmente em solo arenoso e profundo, apresentando espécimes com hábito arbustivo de densidade variável; mata úmida, com os tipos Floresta Perenifólia Costeira, comumente denominada como Mata Atlântica, e Floresta Perenifólia de altitude ou mata do brejo (Moreira et al. 1985); e agreste, caracterizado por ser uma área de transição climática, onde os ventos aquecidos na zona de depressão elevam-se e resfriam-se dando origem às chuvas (Rodriguez 2000), e formada por Florestas Subcaducifólia e Caducifólia (Beltrão et al. 2005). Ainda nesse cenário, destaca-se a caatinga, por apresentar vegetação adaptada ao déficit hídrico, tornando- se frequente a ocorrência de plantas suculentas e florestas arbóreas ou arbustivas, com muitas espécies apresentando espinhos e microfilia, dentre outras características xerofíticas (Prado 2003).

Esse estudo foi baseado na análise de espécimes depositados nos herbários EAN, HST (não indexado), IPA, JPB e PEUFR e complementado com trabalhos de campo realizados em 19 municípios do estado. O material coletado foi processado de acordo com as técnicas usuais em taxonomia vegetal propostas por Judd et al. (2009). Flores e frutos foram fixados em álcool $70 \%$ e observados no Laboratório de Botânica da Universidade Estadual da Paraíba (UEPB, Campus I, Campina Grande), com o auxílio de estereomicroscópio. Após o processo de herborização, os exemplares foram depositados no Herbário Manuel de Arruda Câmara (ACAM, não indexado), da Universidade Estadual da Paraíba (UEPB).

Com base nos espécimes analisados, foram elaboradas descrições e uma chave de identificação para as espécies, além de ilustrações contendo os caracteres relevantes das mesmas. Também são apresentados dados de distribuição geográfica, habitat e período de floração e/ou frutificação das espécies. Para a confecção das descrições utilizaram-se as terminologias sugeridas por Radford et al. (1974) e Harris \& Harris (2001). A descrição de estruturas reprodutivas das espécies $P$. capsularis L., P. glandulosa Cav., P. misera Kunth, P. mucronata Lam., P. silvestris Vell., P. suberosa L. e P. watsoniana Mast. foi complementada com base em literatura especializada (Cervi 1997; Cervi \& Dunaiski-Junior 2004; Nunes \& Queiroz 2006). As identificações foram baseadas em obras clássicas e atuais de Passifloraceae (Linnaeus 1753; Masters 1871, 1872; De Candolle 1891; Killip 1938; Escobar 1988; Cervi 1997; Nunes \& Queiroz 2006).

Os nomes vulgares citados no trabalho procedem das exsicatas consultadas e foram também fornecidos por moradores que residem nas proximidades das áreas coletadas durante a realização dos trabalhos de campo.

\section{Resultados e Discussão}

Passiflora L., Sp. Pl. 2: 955.1753.

Trepadeiras inermes, herbáceas, raramente lenhosas, com gavinhas; caule cilíndrico ou quadrangular, glabro ou às vezes hirsuto. Estípulas 
lineares, foliáceas ou setáceas, persistentes, ocasionalmente caducas. Pecíolo geralmente provido de glândulas sésseis ou pedunculadas; lâminas alternas, pecioladas, simples, inteiras ou lobadas, margem inteira, denteada ou serrilhada, algumas vezes com glândulas nos sinus. Pedúnculo único, isolado, inserido na axila foliar; brácteas-3, foliáceas ou membranáceas, verticiladas, involucrais ou alternas, margem inteira ou pinatissecta, algumas vezes hirsutas, persistentes ou caducas. Flores axilares, pareadas ou isoladas, eretas ou pêndulas raramente em inflorescência; hipanto cilíndrico ou campanulado; sépalas-5, carnosas ou membranáceas, corniculadas dorsalmente próximo ao ápice, oblongas, espatuladas ou ovadas, margem inteira; pétalas-5, alternas às sépalas, membranáceas, algumas vezes ausentes; filamentos da corona com uma a várias séries, filiformes, ocasionalmente tubulares, raramente unidos, ápices eretos ou frisados; opérculo localizado na base do androginóforo, membranáceo, margem inteira ou plicada, inteiro, raramente ausente; disco nectarífero próximo ao opérculo, algumas vezes ausente; límen anular ou cupuliforme envolvendo a base do androginóforo; filetes glabros, verdes ou amarelados, estames-5, livres entre si; anteras-5, rimosas, dorsifixas. Ovário súpero, globoso, ovoide ou fusiforme, glabro ou velutino, 3-carpelar, pluriovulado, placentação parietal, estiletes-3. Fruto baga, costado ou liso, raramente cápsula, indeiscente, apresentando polpa mucilaginosa, superfície opaca ou lustrosa. Sementes numerosas, levemente comprimidas, reticuladas, foveoladas, envoltas por um arilo mucilaginoso.

No Brasil ocorrem quatro gêneros e 144 espécies de Passifloraceae, das quais 136 pertencem ao gênero Passiflora L. (Bernacci et al. 2014). Na Paraíba, foram registradas 11 espécies, todas pertencentes ao gênero Passiflora e, distribuídas em todas as mesorregiões do estado (Fig. 1).

\section{Chave de identificação para as espécies de Passiflora do Estado da Paraíba}

1. Fruto cápsula

2. Passiflora capsularis

1'. Fruto baga

2. Lâmina foliar inteira, nunca lobada

3. Estípulas lineares, linear-subuladas ou setáceas

4. Caule quadrangular; glândulas 2, sésseis, no ápice do pecíolo..........1. Passiflora alata

4'. Caule cilíndrico ou subanguloso; glândulas 2, sésseis, na porção mediana do pecíolo..

3'. Estípulas foliáceas

6. Passiflora glandulosa

5. Lâmina foliar oblongo-lanceolada, ápice obtuso e base arredondada a cordada; pecíolo com glândulas estipitadas na porção mediana 9. Passiflora silvestris

5. Lâmina foliar ovada, ápice emarginado e base cordada; pecíolo com glândulas sésseis na porção mediana.

8. Passiflora mucronata

2'. Lâmina foliar 2-5- lobada

6. Estipulas foliáceas, reniformes.

11. Passiflora watsoniana

6'. Estípulas lineares

7. Lâmina foliar palmada, 5-lobada

3. Passiflora cincinnata

7'. Lâmina foliar 2-3-lobada ou com lobos reduzidos, ou ausentes na folha jovem

8. Lâmina foliar com manchas ocelares nas porções mediana e basal......

8'. Lâmina foliar sem manchas ocelares

7. Passiflora misera

9. Caule pubescente; lâmina foliar com tricomas glandulares na face abaxial; estípulas pinatissectas

5. Passiflora foetida

9'. Caule esparsamente viloso ou glabro; lâmina desprovida de tricomas glandulares na face abaxial; estípulas inteiras

10. Caule glabro; lâmina foliar desprovida de glândulas nos sinus 10. Passiflora suberosa

10'. Caule esparsamente viloso; lâmina foliar portando glândulas sésseis nos sinus 4. Passiflora edulis 
1. Passiflora alata Curtis, Bot. Mag. 1: pl 66. 1781.

Figs. 1; 2a-b; 4a-b

Trepadeira inerme; caule quadrangular, ângulos alados, estrias longitudinais, glabros, gavinhas; presentes. Estípulas ca. $8 \times 3-8 \mathrm{~mm}$, persistentes, lineares, inteiras, ápice agudo, base simétrica, margem inteira. Pecíolo $1-2,5 \mathrm{~cm}$ compr., glabro, glândulas 2, sésseis, globosas, alaranjadas, situadas no ápice do pecíolo; lâmina 6-14,5 × 3,5-10 cm, inteira, ovada, coriácea, ápice agudo, base cordada, margem inteira, peninérvea, nervuras secundárias reticuladas, glândulas ausentes, manchas ocelares ausentes. Pedúnculo 2-3 cm compr., glabro, não articulado; brácteas $3-4 \times 2-2,5 \mathrm{~cm}$, persistentes, verdes em ambas as faces, verticiladas, membranáceas, oblongo-ovadas, ápice obtuso, margem com 4-7 glândulas sésseis por bráctea. Flores $8,5-9,5 \mathrm{~cm}$ diâm., pêndulas, solitárias; hipanto 1-1,5 cm compr., campanulado, verde; sépalas 3,5-4 $\times$ $1,5-2 \mathrm{~cm}$, carnosas, robustas, oblongas, glabras, face externa corniculada e verde, face interna magenta, ápice obtuso, margem inteira; pétalas 3-4,5 × 1-1,5 cm, carnosas, vináceas, oblongas, ápice obtuso, margem inteira; filamentos da corona em 4 séries, 2 séries externas com filamentos 4-5 cm compr., subulados bandeados de cor branca, roxa e violáceo nas extremidades, 2 séries internas com filamentos $0,3-0,4 \mathrm{~cm}$ compr., tuberculados, rosados; opérculo membranoso, ca. $1 \mathrm{~mm}$ alt., circundando a base do androginóforo, margem denteada; límen anular, ca. $3 \mathrm{~mm}$ alt., carnoso, disco nectarífero presente; androginóforo 2-4 $\mathrm{cm}$ alt.; estiletes 3 , verde-claro; filetes 3 ; ovário oblongo ou obovado, glabro. Baga imatura subglobosa, 7-9,5 × 4-5 cm, glabra, verde; sementes não observadas.

Material examinado: BRASIL. Paraíba: Areia, 11.XI.2011, fl. e fr., E.C.S. Costa 10 (ACAM).

Passiflora alata é popularmente conhecida como maracujá-doce, sendo uma espécie nativa da América do Sul, cuja distribuição se estende do leste do Brasil até Nordeste do Peru (Killip 1938). No Brasil, apresenta ampla distribuição, ocorrendo de norte a sul e englobando quase todos os estados brasileiros (Bernacci et al. 2014). Passiflora alata é frequentemente cultivada (Nunes \& Queiroz 2001) e, no estado da Paraíba, foi coletada no município de Areia (Fig. 1), ocorrendo espontaneamente em área de mata Atlântica. $O$ fruto é de consumo caseiro e não comercial. Encontrada com flores e frutos no mês de novembro.
Passiflora alata pode ser facilmente reconhecida por apresentar caule quadrangular, lâmina foliar alongada e ovada, flores exuberantes, pêndulas, com filamentos subulados bandeados de branco e roxo-violáceo nas extremidades e pelo fruto subgloboso, glabro, verde quando imaturo.

\section{Passiflora capsularis L., Sp. Pl. 2: 957. 1753.}

Figs. 1; 3a-d

Trepadeira inerme; caule cilíndrico 3-estriado, pubescente, gavinhas presentes. Estípulas 3-5 $\times$ ca. $1 \mathrm{~mm}$, persistentes, lineares, inteiras, ápice agudo, margem inteira. Pecíolo 1,5-3,2 cm compr., glabro, glândulas peciolares presentes; lâmina $4-8,7 \times$ 3,5-8 cm, 2-3-lobada; cordada, membranácea, ápice mucronado, base simétrica, margem inteira, lobo central geralmente reduzido; lobos laterais 4-6 $\times 1,5-2,5 \mathrm{~cm}$, lobos centrais quando presentes 4,5-7,5 × 1,8-2,5 cm, 3-nervada, manchas ocelares ausentes. Pedúnculo 2,5-3 cm compr., pubescente, não articulado; brácteas caducas. Flores ca. $1,5 \mathrm{~cm}$ diâm., eretas, solitárias, brancas, hipanto $0,4-0,6$ cm compr., tubular, verde; sépalas ca. $1 \times 0,3 \mathrm{~cm}$, carnosas, pubescentes na face externa, oblongas, aristadas, corniculadas, brancas na face externa, verdes na face interna, margem inteira; pétalas 1,9-2,5 × 0,5-1 cm, membranáceas, brancas, margem inteira, oblongas, ápice agudo; filamentos da corona em 2 séries, séries $0,5-1 \mathrm{~cm}$ compr., filiformes, brancas; opérculo membranoso, ca. $1 \mathrm{~mm}$ alt., plicado, margem denticulada; límen disciforme, ca. $1 \mathrm{~mm}$ alt., obstruindo a passagem do hipanto na altura do opérculo, disco nectarífero presente; androginóforo ca. $1 \mathrm{~cm}$ alt.; estiletes 3 , esverdeados, ápice amarelo; filetes 3; ovário elipsoide, pubescente. Cápsula elipsoide, 2,5-3,5 $\times 1-1,7 \mathrm{~cm}$, deiscência longitudinal, avermelhada quando imatura, 6-costada, vilosa; sementes 0,3-0,5 cm compr., alongadas, reticuladas.

Material examinado: BRASIL. Paraíba: Areia, 17.III.1992, fr., L.P. Felix 4758 (EAN); 06.XI.1994, fl. e fr., R. Vieira-Neto 24 (EAN).

Material adicional examinado: BRASIL. Bahia: Área do CEPEC, Km-22, Rodovia Ilhéus/Itabuna (BR-415), 50 m.s.n.m., 05.V.1981, fl. e fr., J.K. Hage et al. 645 (CEPEC, HRB, HUEFS).

Passiflora capsularis pode ser encontrada desde as Antilhas e Guatemala até Costa Rica, Colômbia, Brasil e Paraguai (Killip 1938). No Brasil, distribui-se nos estados do Pará, Piauí, Bahia, Goiás, Mato Grosso do Sul, Minas Gerais, Espírito Santo, São Paulo, Rio de Janeiro, Paraná, Santa Catarina e Rio Grande do Sul (Bernacci et al. 


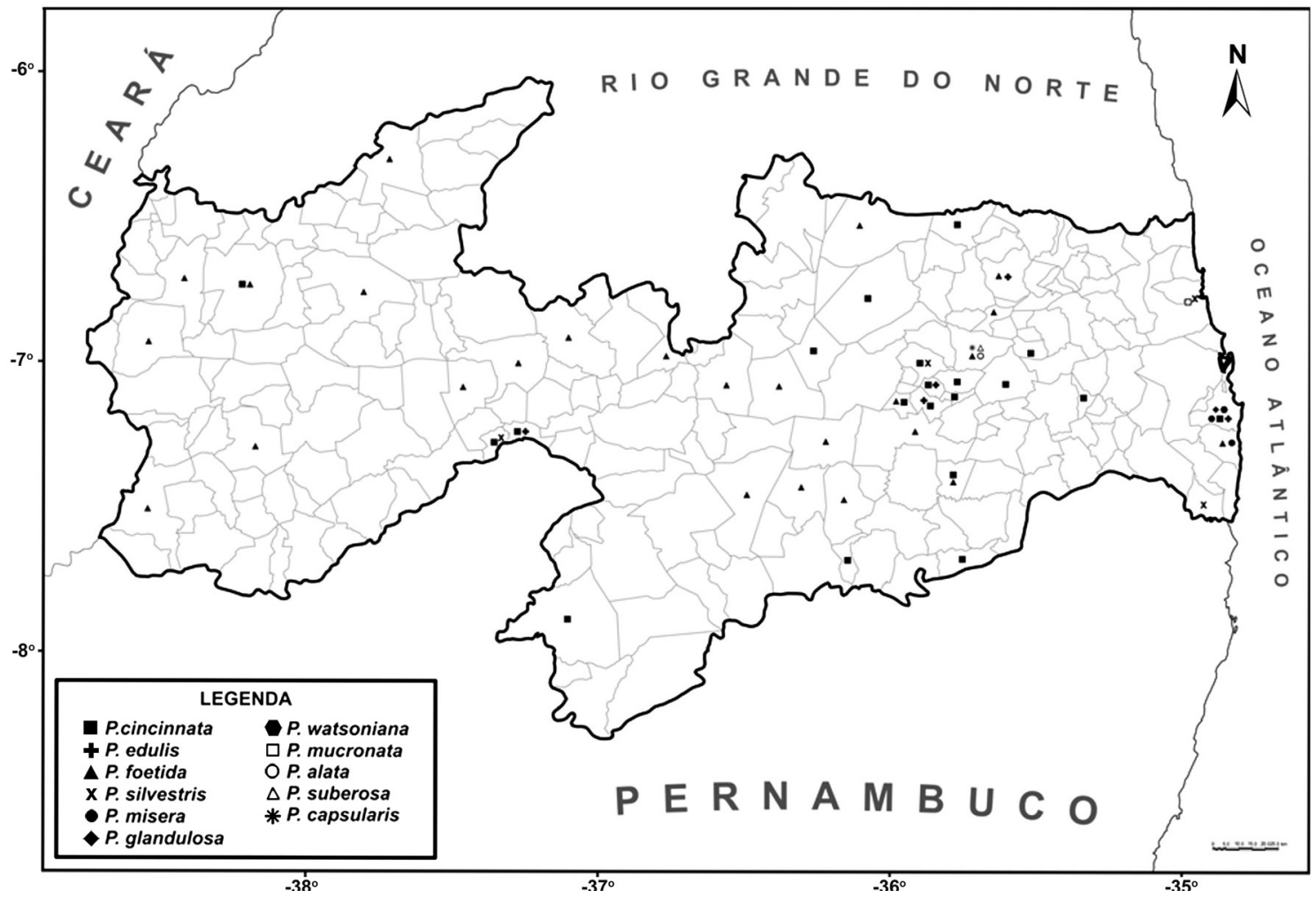

Figura 1- Distribuição geográfica das espécies de Passifloraceae do Estado da Paraíba. Figure 1 - Geographical distribution of Passifloraceae species in Paraíba state.

2014). Na área de estudo, foi encontrada na Reserva Ecológica Mata do Pau Ferro, em Areia, no brejo Paraibano (Fig. 1), representando, nesse trabalho, o primeiro registro da espécie para o estado. Floresce e frutifica nos meses de março e novembro.

Dentre as demais espécies registradas para a Paraíba, caracteriza-se por apresentar o fruto com abertura longitudinal. Outras características como fruto viloso, costado, e folhas com lâminas 2-3-lobadas, com o lobo central geralmente atrofiado ou inconspícuo, também permitem o pronto reconhecimento da espécie.

\section{Passiflora cincinnata Mast., Gard. Chron. 37:} 966. 1868.

Figs. 1; 2c-d; 4e

Trepadeira inerme; caule cilíndrico, glabro, estriado, gavinhas presentes. Estípulas 7-12 $\times$ ca. $1 \mathrm{~mm}$, persistentes, lineares, inteiras, ápice agudo, margem levemente serrilhada. Pecíolo 2-5 cm compr., pubescente, glândulas 2, sésseis, orbiculares, verdes, situadas na base do pecíolo; lâmina $6,5-11,5 \times 5-7,5 \mathrm{~cm}$, palmada, 5-lobada, membranácea, ápice agudo, base aguda, margem levemente serrilhada, 1-2 glândulas sésseis nos sinus, 5-nervada, manchas ocelares ausentes. Pedúnculo 0,5-1 cm compr., glabro, não articulado; brácteas 4-4,3 × 2,5-3 cm, persistentes, externamente verdes, internamente brancas, verticiladas, membranáceas, oblongas, margem inteira, 3-6-glândulas sésseis ou pedunculadas na base, ápice agudo. Flores 10,5-11 cm diâm., eretas, solitárias; hipanto 0,5-1 cm compr., campanulado, verde; sépalas 2-5,2 $\times 1,5-1,7 \mathrm{~cm}$, oblongas, glabras, corniculadas, corno velutino, ápice agudo, margem inteira; pétalas 4,5-5 × 1-1,2 cm, membranáceas, violáceas, margem inteira, oblongas, ápice obtuso; filamentos da corona dispostos em várias séries, frisados no ápice, séries externas de 3-5,2 cm compr., séries internas entre 1-1,2 cm compr., opérculo membranoso, ca. $10 \mathrm{~mm}$ alt., fundido na base dos filamentos internos; límen ca. $4 \mathrm{~mm}$ alt., carnoso, margem inteira, envolto na base do androginóforo, este ca. $1 \mathrm{~cm}$ compr., ereto, carnoso, disco nectarífero presente; estiletes 3, esverdeados, filetes 3; ovário globoso, glabro. 

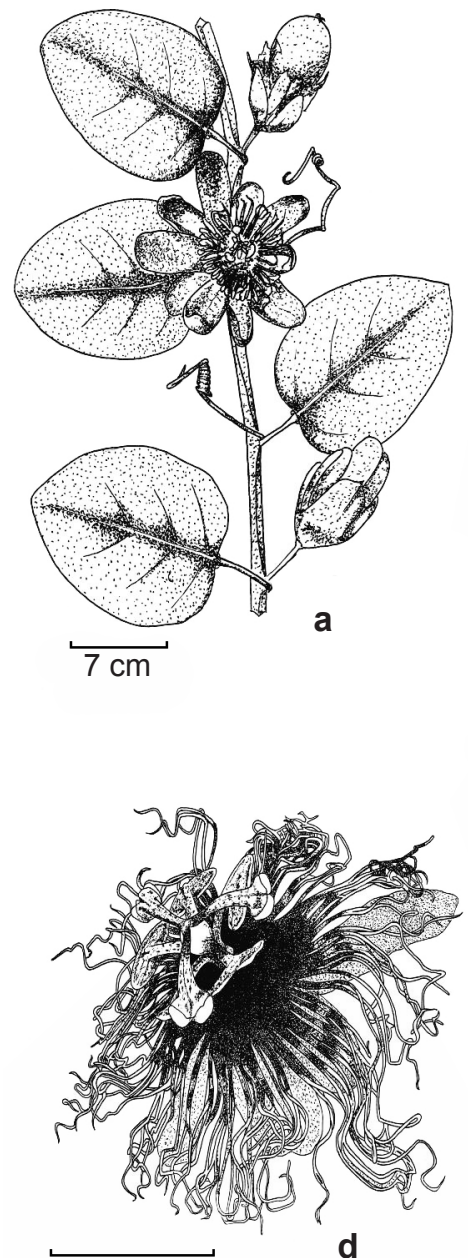

$4 \mathrm{~cm}$
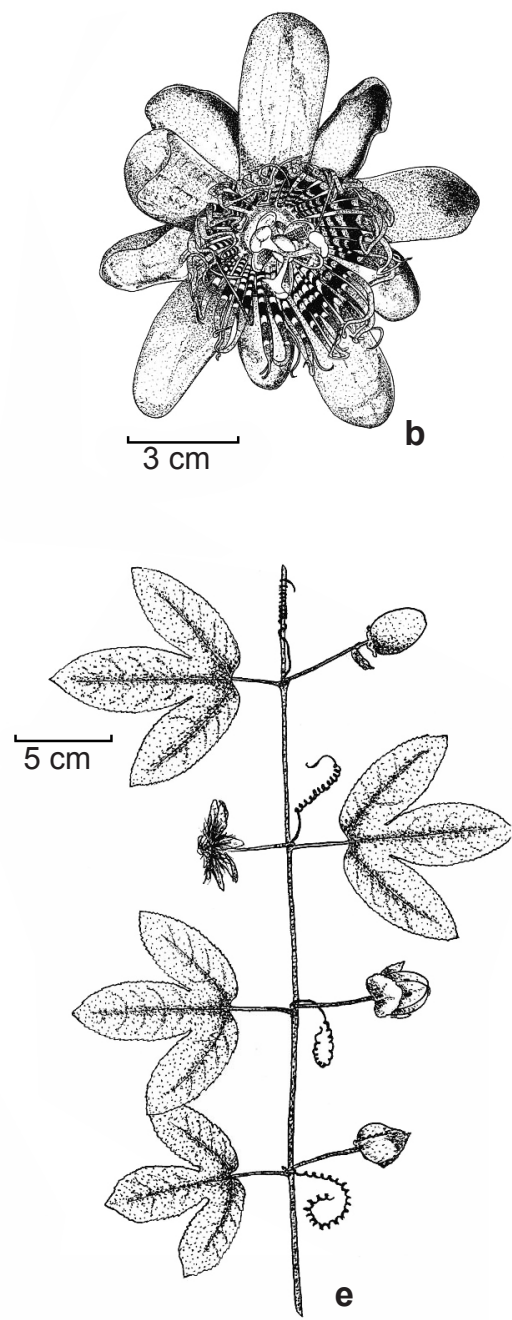
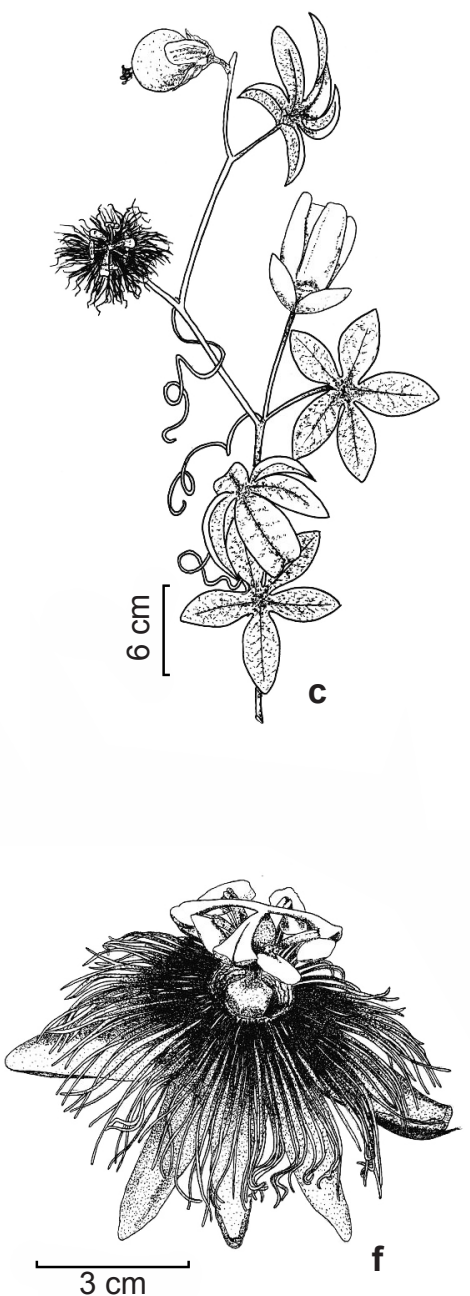

Figura 2 - a-b. Passiflora alata - a. ramo reprodutivo; b. flor em vista frontal (E.C.S. Costa 10). c-d. Passiflora cincinnata - c. ramo reprodutivo; d. flor em vista lateral (E.C.S. Costa 05). e-f. Passiflora edulis - e. ramo reprodutivo; f. flor em vista lateral (E.C.S. Costa 03).

Figure 2 - Passiflora alata - a. reproductive branch; b. flower in frontal view (E.C.S. Costa 10). c-d. Passiflora cincinnata - c. reproductive branch; d. flower in lateral view (E.C.S. Costa 05). e-f. Passiflora edulis - e. reproductive branch; f. flower in lateral view (E.C.S. Costa 03).

Baga imatura globosa, 17-17,5 cm diâm., glabra, verde-escuro; sementes ca. $0,5 \mathrm{~cm}$ compr., ovadas, levemente achatadas, alveoladas.

Material examinado: BRASIL. Paraíba: Alagoa Nova, 09.XI.1951, fl., L.P. Xavier (JPB 1816); Alagoinha, 12.X.1942, fl., L.P.Xavier (JPB 1016); Araruna, 16.II.2004, fl., M.R. Barbosa et al. 2852 (JPB); Barra de Santa Rosa, 11.III.1988, fl., L.P. Felix 12129 (EAN); Caldas Brandão, 18.III.1980, fl., M.F. Agra 240 (JPB); Fagundes, 18.III.2012, fl. e fr., E.C.S. Costa 22 (ACAM); João Pessoa, 04.IX.1941, fl., L.P. Xavier (JPB 249); 02.V.1991, fl., O.T. Moura 615 (JPB); 10.X.1997, fl., A.C. Portela 02 (JPB); Lagoa Seca, 06.I.2012, fl. e fr., E.C.S. Costa 12 (ACAM); Matinhas,
17.IV.2011, fl. e fr., E.C.S. Costa 02 (ACAM); Maturéia, 20.XI.1997, fl., M.F. Agra \& K.N. Silva 4388 (JPB); 21.I.1998, fl., M.F. Agra et al. 4692 (JPB); 23.IV.1998, fl., M.F. Agra et al. 5221 (JPB); Monteiro, 22.V.2008, fl. e fr., P.C. Gadelha-Neto \& M.C. Pessoa 2291 (JPB); Olivedos, 12.XI.2011, fr., E.C.S. Costa 11 (ACAM); Puxinanã, 27.V.2011, fl. e fr., E.C.S. Costa 05 (ACAM); Riacho de Santo Antônio, 27.VII.2011, fl. e fr., E.C.S. Costa 06 (ACAM); São Sebastião de Lagoa de Roça, 17.IV.2011, fl. e fr., E.C.S. Costa 01 (ACAM); Sousa, 1931-1938, fl., P. Luetzelburg 26409 (IPA); Teixeira, 27.II.1994, fr., M.F. Agra et al. 2649 (JPB); Umbuzeiro, 24.VIII.1952, fl., L.P. Xavier (JPB 1688). 
Espécie amplamente distribuída na América do Sul, alcançando o Brasil, Paraguai, Argentina, Bolívia, Venezuela e Colômbia (Killip 1938). No Brasil, ocorre nas Regiões Norte, Nordeste, CentroOeste e Sudeste (Bernacci et al. 2014), em áreas de caatinga, cerrado, mata estacional e em campos rupestres (Nunes \& Queiroz 2006). Na Paraíba, foi encontrada em áreas de caatinga, geralmente próxima a inselbergs ou em margens de estradas (Fig. 1). Encontrada com flores de janeiro a outubro e frutificada de janeiro a novembro.

Esta espécie pode ser facilmente reconhecida pela lâmina foliar palmada, 5-lobada, apresentando glândulas sésseis nos sinus, flores vistosas, de corola arroxeada, com filamentos frisados no ápice e filetes e anteras verdes com máculas vináceas.

4. Passiflora edulis Sims, Bot. Mag. 45: 1989. 1818.

Figs. 1; 2e-f; $4 \mathrm{f}$

Trepadeira inerme; caule cilíndrico, estriado, esparsamente viloso, gavinhas presentes. Estípulas ca. $5 \times 1 \mathrm{~mm}$ compr., persistentes, lineares, inteiras, ápice mucronado, margem inteira. Pecíolo 1,7-2 cm compr., glabro, glândulas 2 , sésseis, orbiculares, verde escuro, situadas no ápice do pecíolo; lâmina 5,5-11 × 5-13 cm, 3-lobada, membranácea quando jovem, subcoriácea quando adulta; lobo central $6,5-10,5 \times 3,5-6 \mathrm{~cm}$, lobos laterais 6-9,5 × 2,5-5 $\mathrm{cm}$, ápice agudo, base cordada, margem serreadodenteada, glândulas sésseis nos sinus, tricomas glandulares ausentes na face abaxial, manchas ocelares ausentes. Pedúnculo $2-4,5 \mathrm{~cm}$ compr., glabro, não articulado; brácteas 2-2,5 × 2,5-3 cm, persistentes, verdes, verticiladas, glabras, foliáceas, margem serreada, glândulas ausentes, ápice agudo. Flores 7,5-9 cm diâm., axilares, cíclicas, eretas,; hipanto $1 \mathrm{~cm}$ compr., campanulado, verde; sépalas 4-4,5 $\times 1,3-1,5 \mathrm{~cm}$, robustas, oblongas, glabras, verdes, ápice corniculado, cornos $0,5-0,7 \mathrm{~cm}$ compr., margem inteira, glândulas 2, sésseis, dispostas lateralmente; pétalas 3,5-4 × 0,5-1 $\mathrm{cm}$, membranáceas, brancas, oblongas, margem inteira, ápice obtuso; filamentos da corona 4-5 séries, duas externas filiformes, $2 \mathrm{~cm}$, duas a três séries internas com tamanhos reduzidos seguido de um progresso dentiforme, variando desde roxo no centro até branco no ápice; opérculo ca. $0,5 \mathrm{~cm}$ compr., membranoso, envolvendo toda a extensão do hipanto, margem levemente ondulada; límen 1 cm compr., cupuliforme, disco nectarífero presente; androginóforo ca. $1 \mathrm{~cm}$ compr., ereto; estiletes 3 , esverdeados, filetes 3; ovário elíptico-ovoide, velutino. Baga globosa, 10-22,5 × 11,5-19,5 cm, verde quando imatura e amarela quando madura, superfície lustrosa com manchas ocelares brancas; sementes $0,5-0,7 \times 0,3-0,4 \mathrm{~cm}$, ovadas, reticuladas ou foveoladas.

Material examinado: BRASIL. Paraíba: Bananeiras, 16.I.2012, fr., E.C.S. Costa 17 (ACAM); João Pessoa, 24.X.1978, fl., M.F. Agra 81 (JPB); 01.IX.1981, fl., E.S. Santana \& N.F. Montenegro 01 (JPB); Lagoa Seca, 06.I.2012, fr., E.C.S. Costa 13 (ACAM); São Sebastião de Lagoa de Roça, 17.IV.2011, fl. e fr., E.C.S. Costa 03 (ACAM); Teixeira, 18.V.2002, fl., M.F. Agra et al. 5873 (JPB).

Passiflora edulis é uma espécie nativa da América do Sul, ocorrendo entre o Paraguai e nordeste da Argentina (Killip 1938; Nunes \& Queiroz 2006). No Brasil, é encontrada espontaneamente ou em plantações comerciais em todo o país. Na Paraíba, é amplamente cultivada em pequenas propriedades da zona rural, mas pode ocorrer espontaneamente próximo a zonas urbanas (Fig. 1). Floresce e frutifica praticamente o ano todo.

Esta espécie é a mais usada no âmbito comercial; a polpa é consumida fresca ou utilizada para produção de sucos e sobremesas (Chitty 2006). Como característica morfológica distintiva apresenta caule cilíndrico estriado. Segundo Escobar (1988), as lâminas apresentam o fenômeno de heteroblastia, onde as folhas na fase jovem possuem forma diferente da fase adulta. As flores por sua vez são adaptadas à polinização de abelhas de grande porte, isto por que a distância entre a face deiscente das anteras e a corola permite uma acomodação precisa de polinizadores maiores realizando com sucesso a fecundação da flor (Siqueira et al. 2009).

\section{Passiflora foetida L., Sp. Pl.: 959. 1753.}

Figs. 1; 3e-g; 4c-d

Trepadeira inerme; caule cilíndrico, não alado, levemente estriado, pubescente, gavinhas presentes. Estípulas 4-10 × 13-15 mm compr., persistentes, lineares, tomentosas, pinatissectas, ápice agudo, margem laciniada. Pecíolo 0,5$1 \mathrm{~cm}$ compr., densamente piloso, glândulas ausentes; lâmina 2,7-4 × 3,5-5 cm, oboval, membranácea, densamente velutina, tricomas glandulares na face abaxial, 3-lobada, lobo central $1,0-2 \times 1,8-2,5 \mathrm{~cm}$, lobos laterais 1,4-2,2 $\times$ $0,8-1,5 \mathrm{~cm}$, glândulas pedunculadas, ápice agudo, mucronado, base cordada, margem serreada, 3nervada, manchas ocelares ausentes. Pedúnculo 
2-3,5 cm compr., pubescente, não articulado; brácteas $2,5-3,5 \times 1-1,3 \mathrm{~cm}$, persistentes, verdes, pinatissectas, verticiladas, com tricomas tectores e glandulares. Flores ca. 5 cm diâm., axilares, cíclicas, solitárias; hipanto ca. $0,4 \mathrm{~cm}$ compr., campanulado, tomentoso, verde; sépalas 2-2,5 $\times$ 0,6-1 cm, membranáceas, oblongas, face externa verde, face interna branca, levemente pilosa, ápice corniculado, margem inteira; pétalas $1,5 \times 0,5 \mathrm{~cm}$, membranáceas, brancas, margem inteira, oblongas, ápice arredondado; filamentos da corona em 5 séries, 2 séries externas com filamentos de 1,5-2 $\mathrm{cm}$ compr., 3 séries internas ca. $0,3 \mathrm{~cm}$ compr., base dos filamentos roxa a azulada, extremidades brancas, ápice frisado; opérculo membranoso, ca. 3 $\mathrm{mm}$ alt., envolvendo toda a base do androginóforo, margem denteada; límen membranoso, ca. $2 \mathrm{~mm}$ alt., margem inteira, disco nectarífero presente; androginóforo ca. $0,8 \mathrm{~cm}$ alt., ereto, glabro; estiletes 3, verdes, filetes 3; ovário globoso, glabro. Baga globosa, 4-6 × 2,3-3 cm, glabra, verde; sementes $0,5-0,7 \times$ ca. $0,3 \mathrm{~cm}$, ovadas a oblongas, parcialmente achatadas, alveoladas.

Material examinado: BRASIL. Paraíba: Alagoinha, X.1941, fl., J.M. Joffily (JPB 405); Bananeiras, 16.I.2012, fl. e fr., E.C.S. Costa 15 (ACAM); 16.I.2012, fl. e fr., E.C.S. Costa 16 (ACAM); Boa Vista, 21.X.2011, fl. e fr., E.C.S. Costa 08 (ACAM); Boqueirão, BR-101, 22.IX.1970, T.J. Soares 76 (PEUFR); 01.VIII.1993, fl., M.F. Agra et al. 2235 (JPB); Cabaceiras, 30.IV.2011, fl., fr., E.C.S. Costa 04 (ACAM); Cajazeiras, 11.V.1982, fl. e fr., C.A.B. Miranda \& O.T. Moura 19 (JPB); Campina Grande, 18.III.2012, fl. e fr., E.C.S. Costa 18 (ACAM); 18.III.2012, fl. e fr., E.C.S. Costa 19 (ACAM); Catolé do Rocha, 26.II.1980, fl., M.F. Agra 225 (JPB); Conceição, 03.VII.2008, fr., P.C. Gadelha-Neto 2455 (JPB); Conde, 12.I.2012, fl. e fr., E.C.S. Costa 14 (ACAM); Cuité, 11.III.2008, fl. e fr., L.P. Felix 12134 (EAN); Fagundes, 18.III.2012, fl. e fr., E.C.S. Costa 20 (ACAM); 18.III.2012, fl. e fr., E.C.S. Costa 21 (ACAM); Itaporanga, 10.I.1994, f1. e fr., M.F. Agra 2471 (JPB); Pombal, 24.IV.1953, fl. e fr., F. Carneiro (JPB 2978); Puxinanã, 29.X.2011, fr., E.C.S. Costa 09 (ACAM); Santa Terezinha, 04.III.2006, fl. e fr., M.F. Agra et al. 6580 (JPB); São João do Cariri, 17.VII.2011, fl. e fr., E.C.S. Costa 07 (ACAM); ); São João do Rio do Peixe, 24.IV.1982, fr., M.A. Sousa et al. 1227 (JPB); São Mamede, 13.VII.2007, fl., M.F. Agra et al. 6950 (JPB); Seridó, 15.VIII.1979, fl., C.A.B. Miranda (JPB 4423); 15.IX.2005, fl. e fr., M.F. Agra 6538 (JPB); Serraria, 12.I.1942, fr., M.C. Espinola (JPB 584); Sousa, 13.X.1995, fl., P. Gadelha-Neto 267 (JPB); 22.VI.1999, fl., O.T. Moura (JPB 24895); 19.I.2000, fl., P.C. Gadelha-Neto et al. 520 (JPB).
Passiflora foetida é amplamente distribuída na América do Sul, ocorrendo também em Porto Rico, Jamaica e nas pequenas Antilhas (Killip 1938). No Brasil, ocorre praticamente em todos os Estados, associada a todos os tipos vegetacionais, sendo caracterizada como invasora, principalmente em áreas degradadas (Nunes \& Queiroz 2006). Na Paraíba, a espécie encontra-se amplamente distribuída (Fig. 1), ocorrendo principalmente em margens de estradas, próxima a áreas antropizadas. Esta espécie também é utilizada para fins medicinais, especialmente no combate a febres altas e como reguladora de transtornos menstruais (Chitty 2006). Floresce e frutifica entre os meses de janeiro a novembro.

Facilmente reconhecível por apresentar indumento densamente piloso no pecíolo e velutino na lâmina foliar, tricomas glandulares na face abaxial da lâmina foliar, corola vistosa com pétalas brancas e filamentos de ápice agudo, brancos na base e lilases nas extremidades, associados às lâminas foliares 3-lobadas, densamente velutinas.

\section{Passiflora glandulosa Cav., Diss. 10: 453. Pl.} 281. 1790.

Fig. 1

Trepadeira inerme; caule cilíndrico ou subanguloso, glabro ou glabrescente, gavinhas presentes. Estípulas caducas, lineares, ca. $3 \times 1 \mathrm{~mm}$. Pecíolo 0,5-1,3 cm compr., glabro, glândulas 2, sésseis na porção mediana; lâmina 7,3-10 × 3,2-4,5 $\mathrm{cm}$, inteira, oblongo-lanceolada, coriácea, glabra em ambas as superfícies, ápice agudo ou acuminado, base cordada ou arredondada, margem inteira ou ligeiramente ondulada, nervuras peninérveas. Pedúnculo 3-6 cm compr., não articulado; brácteas $0,4-0,5 \mathrm{~cm}$, verdes, linear-lanceoladas, margem inteira com glândulas nas margens, ápice agudo. Flores 2,3-2,5 diâm., eretas, solitárias, vermelhas ou escarlates; hipanto $0,4 \mathrm{~cm}$ alt., cilíndrico; sépalas $2-3 \times 0,3-0,5 \mathrm{~cm}$, carnosas, oblongas ou linear-oblongas, corniculadas, vermelhas; pétalas $2-2,5 \times 0,5-0,7 \mathrm{~cm}$, membranáceas, vermelhas ou escarlate, margem inteira, oblongas, ápice agudo; filamentos da corona em 2 séries, série externa ca. $1 \mathrm{~cm}$ de compr., série interna $0,2-0,5 \mathrm{~cm}$ compr., livres na base, alvos ou levemente rosáceos; opérculo ca. $3 \mathrm{~cm}$ compr.,membranoso, margem recurvada, ápice filamentoso, límen membranáceo, ca. $2 \mathrm{~mm}$ alt., cupuliforme, ereto envolvendo a base do androginóforo; androginóforo ca. $2 \mathrm{~cm}$ compr., ereto, glabro; estiletes 3, verdes, filetes 3; ovário elipsoidal, glabro ou às vezes puberulento. Baga ovoide, $3,5-5 \times 1,3-2 \mathrm{~cm}$, pericarpo coriáceo; sementes não observadas. 

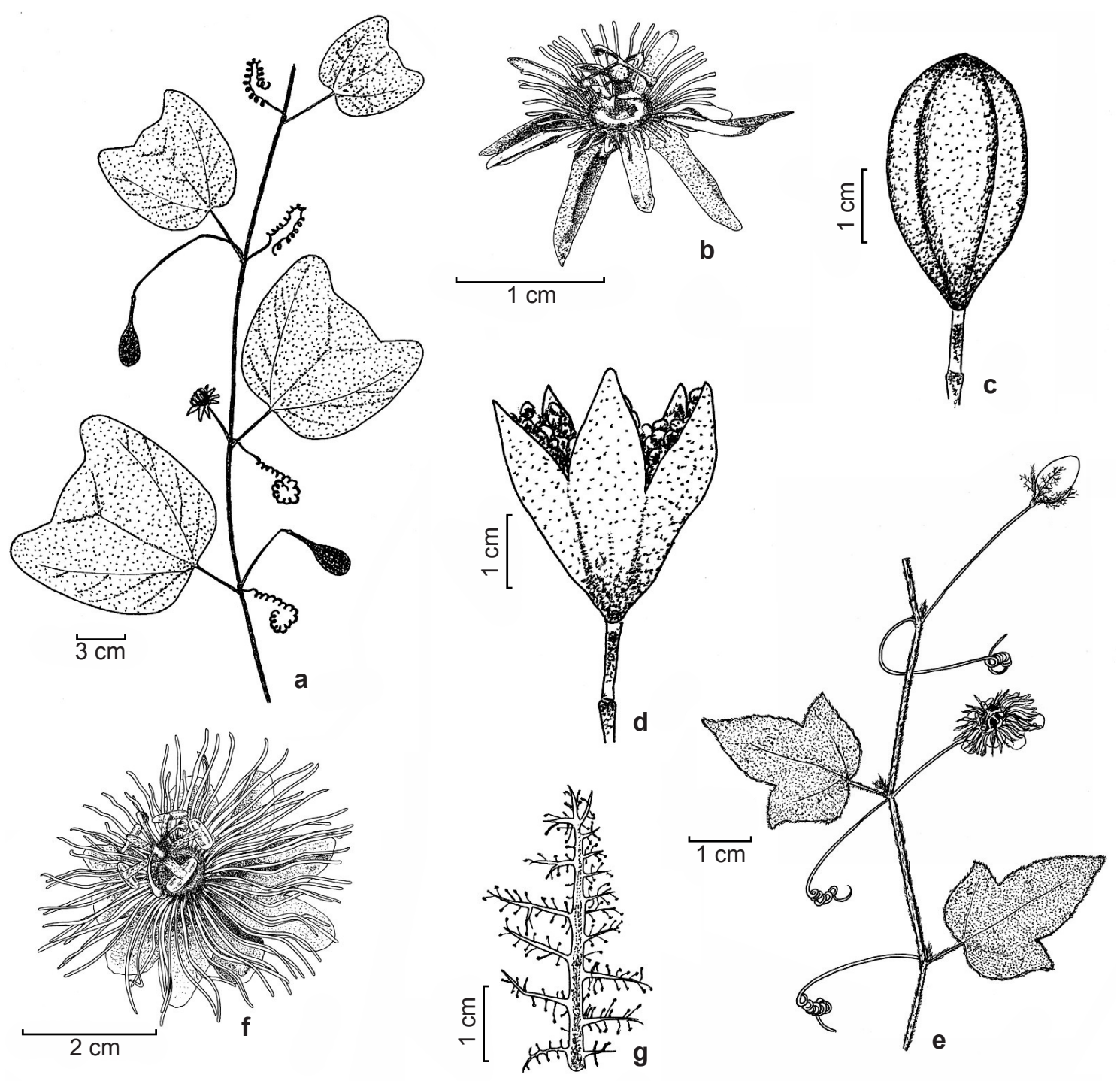

Figura 3 - a-d. Passiflora capsularis - a. ramo reprodutivo; b. flor em vista frontal; c. fruto; d. fruto evidenciando abertura longitudinal (R. Vieira-Neto 24). e-g. Passiflora foetida - e. ramo reprodutivo; f. flor em vista frontal; g. bráctea com tricomas glandulares (E.C.S. Costa 15).

Figure 3 - a-d. Passiflora capsularis - a. reproductive branch; b. flower in frontal view; c. fruit; d. fruit showing the longitudinal opening (R. Vieira-Neto 24). e-g. Passiflora foetida - e. reproductive branch; f. flower in frontal view; g. bract with glandular trichomes (E.C.S. Costa 15).

Material examinado: BRASIL. Paraíba: João Pessoa, 20.III.1984, fl. e fr., O.T. Moura 178 (JPB).

Material adicional examinado: BRASIL. Maranhão: Peritoró, 26.IX.1983, fl. e fr., M.A. Sousa et al. 1089 (JPB).

Ocorre desde as Guianas passando pelo Norte, Nordeste até o Centro-Oeste do Brasil (Killip 1938; Bernacci et al. 2014), com exceção do Rio de Janeiro onde é cultivada (Cervi \& Dunaiski-Junior 2004). Passiflora glandulosa é frequentemente encontrada na orla e clareiras de floresta (Cervi \& Dunaiski-Junior 2004). Na Paraíba, foi coletada em área de restinga (Fig. 1) com flores e frutos nos meses de março a setembro.

Em campo, pode ser reconhecida pelas folhas simples, inteiras, e lustrosas, bem como por apresentar duas glândulas sésseis na porção mediana do pecíolo e brácteas linear-lanceoladas portando glândulas. Suas flores são vistosas, vermelhas, e o fruto apresenta pericarpo coriáceo. 
7. Passiflora misera Kunth, Nov. Gen. \& Sp. 2: 136. 1817. Fig. 1

Trepadeira inerme; caule anguloso, glabro ou esparsamente pubescente, com estrias longitudinais, gavinhas presentes. Estípulas $0,4-0,5 \mathrm{~cm}$, caducas, lineares, inteiras, ápice agudo, margem inteira. Pecíolo 1,3-2 cm compr., glabro, glândulas ausentes; lâmina 1,2-3 ×6,5-12 cm, membranácea, pubescente em ambas as faces, 2-3-lobada por atrofia do lobo central, 3-nervada, ápice acuminado, base truncada, margem inteira, levemente revoluta; lobos laterais agudos, raramente arredondados no ápice, oblongos, 2 máculas ocelares localizadas na base da lâmina, próximo à inserção do pecíolo, 4 máculas ocelares presentes na região mediana da lâmina foliar. Pedúnculo $3,2-4,5 \mathrm{~cm}$ compr., pubescente; isolado, não articulado; brácteas caducas. Flores 1,5-3 cm diâm., eretas, solitárias, verde-clara, hipanto campanulado, 0,4-,6 cm compr., verde; sépalas $1-1,3 \times$ ca. $0,4 \mathrm{~cm}$, carnosas, pubescentes, oblongo-lanceoladas, verde-claras, ápice agudo, corniculadas, margem inteira; pétalas 1-1,2× ca. 0,3 cm, membranáceas, linear-oblongas, ápice agudo; filamentos da corona em 2 séries, série externa ca. $1 \mathrm{~cm}$ de comprimento, série interna ca. $0,3 \mathrm{~cm}$ compr.; opérculo membranoso, plicado, límen ausente; disco nectarífero presente; androginóforo $0,7-1 \mathrm{~cm}$ compr., ereto; estiletes 3 , esverdeados, filetes 3; ovário oblongo a elíptico, glabro. Baga ovada a elipsoide, 1,5-2 × 1,5-2 cm, violáceo-escura, glabra; sementes ca. $0,4 \times 0,2 \mathrm{~cm}$, ovadas, transversalmente sulcadas.

Material examinado: BRASIL. Paraíba: Areia, 20.IV.1945, fl., J.C. Morais (EAN 402); Conde, 11.VII.2008, fr., R. Lima et al. 2471 (JPB); João Pessoa, 01.VIII.1994, fl., O.T. Moura (JPB 24058).

Material adicional: BRASIL. Bahia: Canavieiras, Ramal a direita depois da ponte, na estrada Una/ Canavieiras, restinga arbórea, 32 m.s.n.m., 07.I.2002, T.S. Nunes et al. 750 (HUEFS).

Distribuição desde o Panamá, alcançando o nordeste e leste da América do Sul até o nordeste da Argentina, preferencialmente em áreas com baixas altitudes (Killip 1938). No Brasil, foi registrada em todas as regiões, no entanto, na região Norte, foi encontrada apenas em Tocantins e Acre. $\mathrm{Na}$ Paraíba, foi encontrada em áreas de capoeira, menos frequente em áreas de caatinga e matas estacionais (Fig. 1). Coletada com flores de abril a agosto e com frutos em julho.

Passiflora misera é prontamente reconhecida por apresentar caule pubescente, anguloso, e as glândulas peciolares, comumente encontradas nas espécies do gênero, encontram-se ausentes nesta espécie. A lâmina foliar também se diferencia das demais espécies registradas na Paraíba, por geralmente apresentar o lobo central atrofiado, e manchas ocelares são encontradas na porção mediana e no ápice da segunda nervura foliar. 8. Passiflora mucronata Lam., Encycl. 3: 33.
1789.

Fig. 1

Trepadeira inerme; caule cilíndrico, levemente estriado, flexível, glabro, gavinhas presentes. Estípulas 1-1,5 × 0,5-1 cm, persistentes, oval-lanceoladas, foliáceas, inteiras, ápice agudo, mucronado, margem inteira. Pecíolo ca. $0,5 \mathrm{~cm}$ compr., glândulas 2, sésseis, situadas na porção mediana do pecíolo; lâmina $2-3 \times 1,7-2,5 \mathrm{~cm}$, inteira, ovada, cartácea, ápice emarginado, base cordada, margem levemente crenada. Pedúnculo ca. $6 \mathrm{~cm}$ compr., glabro, isolado, não articulado; brácteas ca. $2,5 \times 1,5 \mathrm{~cm}$, persistentes, oblongolanceoladas, mucronado, margem inteira, glândulas ausentes, ápice agudo. Flores 4-4,5 cm diâm., eretas, solitárias, brancas, axilares; hipanto ca. 0,3-0,6 cm, campanulado, verde; sépalas ca. 5,5 $\times 1 \mathrm{~cm}$, corniculadas, glândulas ausentes, ápice obtuso, margem inteira; pétalas ca. $2 \times 0,4 \mathrm{~cm}$, membranáceas, lineares a oblongas, ápice obtuso, margem inteira; filamentos da corona em 2 séries, série externa ca. $1 \mathrm{~cm}$ compr., série interna 0,2-0,4 cm; opérculo ca. $0,2 \mathrm{~cm}$ compr., margem filamentosa, límen cupuliforme, carnoso, disco nectarífero presente; androginóforo ca. $2 \mathrm{~cm}$ alt.; estiletes 3, verdes, filetes 3; ovário ovoide, glabro. Baga globosa, 4-5 × ca. 2,5 cm diâm., ovoide ou elíptico-fusiforme, 6-costada; sementes ca. 0,5 × $0,3 \mathrm{~cm}$, ovadas, oblongo-obcordadas, achatadas, foveoladas.

Material examinado: BRASIL. Paraíba: Barra de Mamanguape, Rio Tinto, 02.II.1989, fl., L.P. Felix (EAN 6317).

Material adicional examinado: BRASIL. Bahia: Ilha da Atalaia, ca. $2 \mathrm{~km}$ da rótula na praia principal, restinga, 24 m.s.n.m., 07.I.2002, fl. e fr., T.S. Nunes et al. 767 (HUEFS).

Endêmica do Brasil, P. mucronata ocorre na porção leste do país; desde a Paraíba até São Paulo (Bernacci et al. 2014). Na área de estudo, foi encontrada em ambiente de restinga (Fig. 1). Do ponto de vista reprodutivo, esta espécie difere das demais espécies congêneres por apresentar antese noturna e a polinização realizada por quirópteros dos gêneros Glassophaga e Carollia (Cervi 1997). Coletada com flores em fevereiro. 
Pode ser reconhecida em campo por apresentar caule cilíndrico, glabro, estípulas foliáceas mucronadas e flores brancas, com sépalas corniculadas. Segundo Nunes \& Queiroz (2001), $P$. mucronata é frequentemente confundida com $P$. silvestris, diferenciando-se desta apenas pelo número de nervuras e formato das folhas; em P. mucronata as nervuras variam entre $3-5$ e a lâmina foliar é cordado-reniforme, enquanto que $P$. silvestris apresenta apenas uma nervura primária e a lâmina foliar é oblongo-lanceolada.

9. Passiflora silvestris Vell., Fl. Flumin. Icon. 9: tab. 74. 1831 ('1827'); Arch. Mus. Nac. Rio de Janeiro 5: 377. 1881.

Fig. 1

Trepadeira inerme; caule cilíndrico, glabro, estriado; gavinhas presentes. Estípulas 1-1,5 × 0,4-1,3 cm, membranáceas, persistentes, foliáceas, ovado-lanceoladas, ápice agudo, mucronado, base oblíqua, margem inteira. Pecíolo ca. 1-1,5 cm compr., glabro, glândulas 2-4, estipitadas, situadas na porção mediana do pecíolo; lâmina 5,2-7,8 × 3-4 cm, inteira, oblongo-lanceolada, membranácea a coriácea, face adaxial lustrosa, face abaxial opaca, ápice obtuso, mucronado, base arredondada a cordada, margem crenada, nervação reticulada. Pedúnculo 4-6,5 cm compr., glabro, articulado ca. $1,2 \mathrm{~cm}$ da base floral; brácteas $3,1-2 \times 0,4-0,6 \mathrm{~cm}$, membranáceas, persistentes, verde-claras, verticiladas, foliáceas, oblongo-lanceoladas a oval-lanceoladas, ápice agudo, mucronado, margem inteira. Flores 6-8 $\mathrm{cm}$ diâm., eretas, solitárias, brancas; hipanto 0,7-1 cm alt., cilíndrico-campanulado, verdevináceo, nervuras longitudinais presentes; sépalas 3-4 × 0,7-0,9 $\mathrm{cm}$, carnosas, brancas, oblongas, carenadas, corniculadas; pétalas 3-4 $\times$ 0,7-0,9 cm, membranáceas, brancas, oblongas; filamentos da corona em 2 séries externas ca. $1 \mathrm{~cm}$ compr., séries internas ca. $0,3 \mathrm{~cm}$ compr., filiformes, brancos; opérculo filamentoso no meio do hipanto, límen cupuliforme, ca. $5 \mathrm{~mm}$ alt., disco nectarífero presente; androginóforo $3-5 \mathrm{~cm}$ alt.; estiletes 3 , verdes, filetes 3 ; ovário elipsoide, glabro, verde-escuro; estiletes verdes com manchas vináceas; estigmas verde-escuros. Baga obovoide a elipsoide, ca. 2,5 $\times 1 \mathrm{~cm}$, glabra, 6 -costada; sementes ca. $0,3 \times 0,4 \mathrm{~cm}$, oblongoovadas, reticuladas.

Material examinado: BRASIL. Paraíba: Areia, 10.XI.1953, fr., J.C. Morais (944 EAN); BR-101, 22.VII.1970, f1., T.J. Soares 70 (PEUFR); Caaporã,
26.V.1992, fl. e fr., A.S. Luz (HST 6166, PEUFR 12350); Esperança, 01.X.1993, fl., L.P. Felix 6169 (EAN); Mamanguape, 29.XI.2006, fl., L.P. Felix \& M.F. Mata 11359 (EAN); 06.VII.2008, fl., S. Satyro \& M.S. Pereira 67 (JPB); Maturéia, 21.I.1998, fl., M.F. Agra et al. 4620 (JPB); 15.V.1998, fr., M.F. Agra et al. 5310 (JPB).

Material adicional examinado: BRASIL. Pernambuco: Buíque, 06.V.1995, fl., A. Laurênio et al. 38 (PEUFR). Bahia: Itapebi, 4,6 Km de Itapebi para Belmonte, mata de restinga, 139 m.s.n.m., 08.I.2002, fl. e fr., T.S. Nunes et al. 769 (HUEFS); $64 \mathrm{Km}$ de Itapebi, mata de restinga, 88 m.s.n.m., 08.I.2002, fl. e fr., T.S. Nunes et al. 809 (HUEFS).

Esta espécie é endêmica do Brasil, ocorrendo nas Regiões Nordeste e Sudeste (Cervi 1997). Segundo Nunes \& Queiroz (2006), ocorre em áreas de campo rupestre, mata atlântica, restinga e cerrado. Na Paraíba, foi encontrada em ambientes de matas estacionais, capoeiras e restinga (Fig. 1). Encontrada florida de janeiro a novembro e frutificada de maio a novembro.

Passiflora silvestris pode ser reconhecida em campo por apresentar caule cilíndrico, estriado, estípulas foliáceas, ovado-lanceoladas, lâmina foliar inteira, coriácea, sépalas e pétalas alvas, corola vistosa, filamentos curtos e fruto glabro, 6-costado.

10. Passiflora suberosa L., Sp. Pl. 2: 958. 1753.

Fig. 1

Trepadeira inerme; caule cilíndrico a achatado, estriado, glabro, gavinhas presentes. Estípulas $0,5-0,7 \mathrm{~cm}$, persistentes, lineares, inteiras, ápice agudo, margem inteira. Pecíolo 1,5-2 cm compr., pubescente; glândulas-2, estipitadas, verde-escuras, situadas na região distal do pecíolo; lâmina 7,3-9 × 5-6 cm, 3-lobada e inteira, membranácea, pubescente nas nervuras, base cuneada a cordada, margem inteira, lobo central 7,5-8,3 × 2,2-3 cm, acuminado, lobos laterais 4-4,2 × 1-1,2 cm, agudos; quando inteiras 5-7 × 1,5-2,5 cm, oval-lanceoladas, glândulas nos sinus ausentes. Pedúnculo 1,5-1,7 cm compr., pubescente, não articulado; brácteas ca. 1,2 × 0,4 cm compr., caducas, verdes, inteiras, pubescentes, ápice agudo, margem inteira. Flores $0,5-3 \mathrm{~cm}$ diâm., eretas, raramente solitárias, amareloesverdeadas, hipanto $0,2-0,4 \mathrm{~cm}$ compr., curtocampanulado, pubescente; sépalas $0,06-0,1 \times$ ca. $0,2 \mathrm{~cm}$, carnosas, pubescentes na face externa, glabras na face interna, amarelo-esverdeadas, ovado-lanceoladas, cornos ausentes, ápice agudo, 

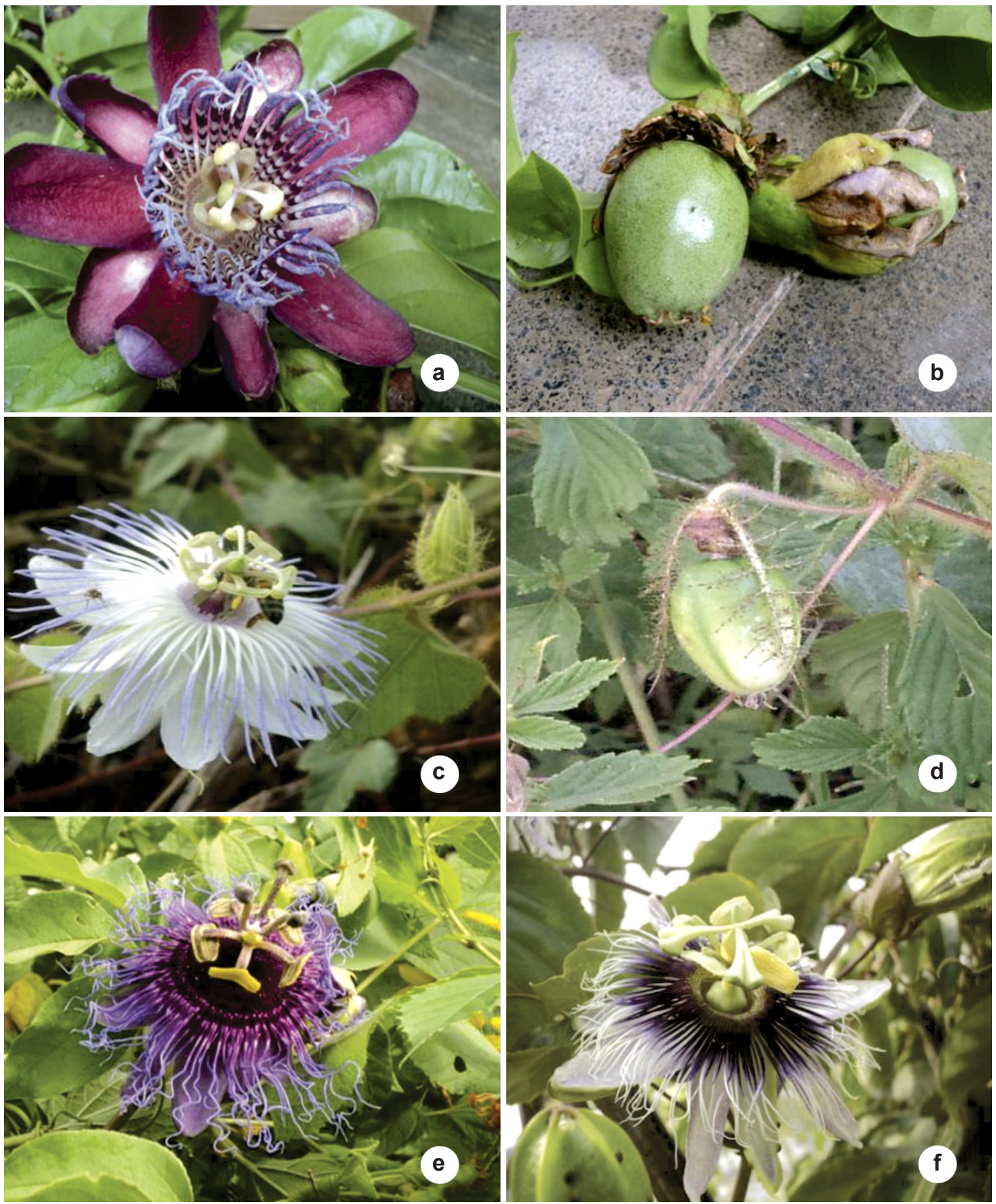

Figura 4 - a-b. Passiflora alata - a. flor; b. fruto imaturo (E.C.S. Costa 10). c-d. Passiflora foetida - c. flor; d. fruto (E.C.S. Costa 08). e. Passiflora cincinnata Mast. - flor (E.C.S. Costa 22). f. Passiflora edulis - flor (E.C.S. Costa 03). Figure 4 - a-b. Passiflora alata - a. flower; b. unripe fruit (E.C.S. Costa 10). c-d. Passiflora foetida - c. flower; d. fruit (E.C.S. Costa 08). e. Passiflora cincinnata - flower (E.C.S. Costa 22). f. Passiflora edulis - flower (E.C.S. Costa 03). 
margem inteira; pétalas ausentes; filamentos da corona em 2 séries, arroxeados; série externa ca. $5 \mathrm{~mm}$ compr., filiforme, verde-amarelada; série interna ca. $1 \mathrm{~cm}$ compr., verde-vináceo; opérculo membranáceo, ca. $2 \mathrm{~mm}$ alt., plicado, branco com listras magento-vináceas, límen anular, disco nectarífero presente; androginóforo $0,8-1 \mathrm{~cm}$ alt.; estiletes 3 , verdes, filetes 3 ; ovário subgloboso ou ovoide, glabro. Baga globosa ou ovoide, ca. 1,3×1 $\mathrm{cm}$, verde-escuro a púrpura quando madura, glabra; sementes ca. $0,4 \times 0,2 \mathrm{~cm}$, achatadas, acuminadas no ápice, reticuladas.

Material examinado: BRASIL. Paraíba: Areia, 31.X.1995, fr., J.E.G. Lima (HST 8117).

Material adicional examinado: BRASIL. Bahia: Estrada para o Capão do Correio, 1.264 m.s.n.m., 15.II.2002, fl. e fr., T.S. Nunes et al. 853 (HUEFS); Jacobina, Serra do Ouro, ca. $5 \mathrm{Km}$ do Hotel Serra do Ouro, próximo ao córrego, 515 m.s.n.m., 06.VI.2001, fl. e fr., T.S. Nunes et al. 340 (HUEFS); Pernambuco: Maraial, 20.IV.1994, fr., A.M. Miranda 1618 \& L.P. Félix (HST); Triunfo, 10.III.1995, fr., A.M. Miranda 2129 \& M.F.O. Pires (HST); 23.V.1995, fr., L.P. Félix 7155 \& M.F.O. Pires (HST); 20.X.1997, fr., A.M. Miranda 2387 (HST).

Está distribuída por toda América tropical, exceto nas Guianas, onde é desconhecida ou pelo menos rara (Killip 1938). No Brasil, ocorre em praticamente todo o país, sendo que na Região Norte a espécie ocorre apenas no estado de Roraima (Bernacci et al. 2014). Encontrada em área de Mata Atlântica, no município de Areia brejo Paraibano, próxima a bordos de estrada (Fig. 1). Seu uso comercial ainda é desconhecido, contudo, por apresentar um sabor agradável, os frutos são consumidos in natura por agricultores (Nunes \& Queiroz 2006). Encontrada com frutos de março a outubro.

Em campo, é prontamente reconhecida por apresentar caule cilíndrico levemente achatado, lâmina foliar 3-lobada, com nervuras pubescentes e ápice do lobo central acuminado, flores pequenas verde-claras, pétalas ausentes e fruto também pequeno, verde quando imaturo e verde-escuro a púrpura quando maduro.

11. Passiflora watsoniana Mast., Gard. Chron. $\mathrm{n}$. ser. 26: 648, fig. 127. 1886.

Fig. 1

Trepadeira inerme; caule cilíndrico, estriado, glabro, gavinhas presentes. Estípulas ca. $0,8-1,2 \times 0,5-1 \mathrm{~cm}$, persistentes, foliáceas, inteiras, reniformes, ovaladas, ápice arredondado, mucronado, base assimétrica, margem serreada. Pecíolo 1,5-4 cm compr., glabro, glândulas-2-3, pedunculadas, verdes, situadas na porção mediana do pecíolo; lâmina 6-7 × 4,4-5 cm, 3-lobada, oboval, membranácea, face adaxial verde-escura, face abaxial violácea, 3-nervada, ápice obtuso, base subpeltada, margem revoluta, glândulas-4 nos sinus; lobo central 3-5 × 1,2-2,5 cm, ápice obtuso; lobos laterais 3,5-4 × 1,5-2,5 cm, ápice obtuso. Pedúnculo 4-6 cm compr., glabro, isolado, não articulado; brácteas ca. $3 \times 1 \mathrm{~mm}$, caducas, verdes, alternas, lineares, margem inteira, ápice agudo, glabras. Flores ca. $5 \mathrm{~cm}$ diâm., eretas, solitárias; hipanto ca. $1 \mathrm{~cm}$ compr., campanulado, verde; sépalas 1,8-2,2 × ca. 0,5 $\mathrm{cm}$, externamente verdes, internamente róseas, oblongas, corniculadas, ápice agudo, margem inteira, glândulas ausentes; pétalas 1,5-2 × ca. $0,5 \mathrm{~cm}$, rosas, oblongas, ápice agudo; filamentos da corona em 5 séries, 2 séries externas ca. $2 \mathrm{~cm}$ compr., filiformes, roxo-esbranquiçados, 3 séries internas 0,4-0,8 cm compr., vináceos, filiformes; opérculo liso, ca. $6 \mathrm{~mm}$ alt., margem filamentosa, límen cupuliforme, adnado ao androginóforo, membranáceo ou membranoso, margem inteira, disco nectarífero presente; androginóforo 1,5-2 cm alt.; estiletes 3, verdes, filetes 3 ; ovário ovoide, circular. Baga globosa, ca. $8 \mathrm{~cm}$ diâm., glabra, verde; sementes ca. $0,3 \times 0,5 \mathrm{~cm}$, ovadas, foveoladas.

Material examinado: BRASIL. Paraíba: João Pessoa, 21.III.2012, fr., E.C.S. Costa 23 (ACAM).

Material adicional examinado: BRASIL. Bahia: Miguel Calmon, Serra das Sete Passagens, Parque Estadual das Sete Passagens, 820 m.s.n.m., 05.IV.2001, fl. e fr., H.P. Bautista et al. 3022 (HRB, HUEFS); Santa Terezinha, Topo da Serra da Jibóia, Mata Higrófila, 02.III.2001, fl. e fr., L.P. Queiroz et al. 6462 (HUEFS).

Espécie endêmica do Brasil, com distribuição concentrada nas Regiões Nordeste e Sudeste e abrangendo a Mata Atlântica e a Caatinga (Bernacci et al. 2014). Na Paraíba, ocorre frequentemente em áreas de Mata Atlântica, localizadas no litoral do Estado (Fig. 1). Coletada com frutos no mês de março.

Em campo pode ser prontamente reconhecida pelo caule cilíndrico, glabro, pecíolo com 2-3 glândulas pedunculadas e lâmina foliar 3-lobada, com glândulas nos sinus e face abaxial de coloração violácea, bem como pelas flores eretas, com pétalas rosa. 


\section{Agradecimentos}

Ao PROPESQ (Programa de Incentivo à PósGraduação e Pesquisa), da Universidade Estadual da Paraíba (UEPB), através do Edital 02/2010, a concessão de bolsa de Iniciação Científica (IC) para realização deste estudo à primeira autora. Aos curadores dos herbários paraibanos (EAN, JPB) e pernambucanos (HST, IPA, PEUFR), a permissão para consulta de seus acervos. Ao Conselho Nacional de Desenvolvimento Científico e Tecnológico (CNPq), a Bolsa de Produtividade em Pesquisa (Proc. n. 302751/2012-2 (PQ-2)) concedida ao terceiro autor.

\section{Referências}

Beltrão, B.A.; Morais, F.; Mascarenhas, J.C.; Miranda, J.L.F.; Junior, L.C.S. \& Mendes, V.A. 2005. Diagnóstico do município de Pocinhos. Projeto cadastro de fontes de abastecimento por água subterrânea Estado da Paraíba. CPRM/PRODEEM, Recife. Pp. 2-4.

Bernacci, L.C.; Cervi, A.C.; Milward-de-Azevedo, M.A.; Nunes, T.S.; Imig, D.C.; Mezzonato, A.C. 2014. Passifloraceae. Lista de Espécies da Flora do Brasil. Disponível em <http://reflora.jbrj.gov.br/jabot/ floradobrasil/ FB182>. Acesso em 30 janeiro 2015.

Bernacci, L.C.; Meletti, L.M.M. \& Soares-Scott, M.D. 2003. Maracujá-doce: o autor, a obra e a data da publicação de Passiflora alata (Passifloraceae). Revista Brasileira de Fruticultura 25: 355-356.

Cervi, A.C. \& Dunaiski-Junior, A. 2004. Passifloraceae do Brasil: estudo do gênero Passiflora L. subgênero Distephana (Juss.) Killip. Revista Estudos de Biologia 26: 45-67.

Cervi, A.C. Passifloraceae do Brasil. 1997. Estudo do gênero Passiflora L., Subgênero Passiflora. Departamento de Botânica. Universidade Federal do Paraná. Fontqueria XLV, Madrid. Pp. 4-6.

Chitty, D.F. 2006. El género Passiflora L. en El Hato Piñero, Estado Cojedes, Venezuela. Acta BotánicaVenezuelica 29: 27-37.

De Candolle, A.P. 1891. Passifloraceae. In: De Candolle, A.P.; De Candolle, A.L. (eds.). Prodromus Systematis Naturalis Regni Vegetabilis. G. Masson, Paris. Pp. 321-338.

Escobar, L.K. 1988. Passifloraceae. In: Flora de Colombia. Universidad Nacional de Colombia, Santafé de Bogotá. Pp. 1-138.

Harris, J.G. \& Harris, M.W. 2001. Plant Identification Terminology: an illustrated glossary. 2 ed. Spring Lake Publishing, Utah. 216 p.

Judd, W.S.; Campbell, C.S.; Kellogg, E.A.; Stevens, P.F. \& Donoghue, M.J. 2009. Sistemática Vegetal: um enfoque filogenético. 3.ed. Artmed, Porto Alegre. Pp. 543-562.

Killip, E.P. 1938. The American Species of Passifloraceae. Associate Curator, Division of plants United States National Museum. Botanical Series. Field Museum of Natural History, Chicago, vol. XIX, part I. Pp. 8-9.

Krosnick, S.E. \& Freudenstein, J.V. 2005. Monophyly and Floral Character Homology of Old World Passiflora (Subgenus Decaloba: Supersection Disemma). Systematic Botany 30: 139-152.

Linnaeus, C. 1753. Passiflora. Species Plantarum. Vol. II. Laurentii Salvii, Holmiae. 673p.

MacDougal, J.M. \& Feuillet, C. 2004. Systematics. In: Ulmer, T.; MacDougal, J.M. (orgs.). Passiflora: Passionflowers of the world. Timer Press Inc., Cambridge (Wilde 1971). Pp. 27.

Masters, M.T. 1871. Contributions to the natural history of the Passifloraceae. Transactions of the Linnean Society 237: 593-645.

Masters, M.T. 1872. Passifloraceae. In: Flora Brasiliensis. Disponível em <http://archive.org/search.php>. Acesso em 10 dezembro 2011. Pp. 531-627.

Moreira, E.R.F.; Carvalho, F.A.F. \& Carvalho, M.G.F. 1985. In: Governo do Estado da Paraíba. Universidade Federal da Paraíba. Atlas Geográfico do Estado da Paraíba. Grafset, João Pessoa. Pp. $12-44$.

Nunes, T.S. \& Queiroz, L.P. 2001. A família Passifloraceae na Chapada Diamantina, Bahia, Brasil. Sitientibus série Ciências Biológicas 1: 33-46.

Nunes, T.S. \& Queiroz, L.P. 2006. Flora da Bahia: Passifloraceae. Sitientibus, Série Ciências Biológicas 6: 194-226.

Prado, D.E. 2003. As Caatingas da América do sul. In: Leal, I.R.; Tabarelli, M. \& Silva, J.M.C. (eds.). Ecologia e conservação da Caatinga. Ed. Universitária da UFPE, Recife. Pp. 3-73.

Radford, A.E.; Dickison, W.C.; Massey, J.R. \& Bell, C.R. 1974. Vascular Plant Systematics. Harper Collins, New York, 891p.

Rodriguez, J.L. 2000. Atlas Escolar da Paraíba. Espaço geo-histórico e cultural. $2^{\mathrm{a}}$ ed. Grafset, João Pessoa. Pp. 25-26.

Siqueira, K.M.M.; Kiill, L.H.P.; Martins, C.F.; Lemos, I.B.; Monteiro, S.P. \& Feitoza, E.A. 2009. Ecologia da polinização do maracujá-amarelo, na região do vale do submédio São Francisco. Revista Brasileira de Fruticultura 31: 1-12.

Souza, V.C. \& Lorenzi H. 2008. Passifloraceae. In: Botânica Sistemática: guia ilustrado para identificação das famílias de Fanerógamas nativas e exóticas no Brasil, baseado em APG II. $2^{\mathrm{a}}$ ed. Instituto Plantarum, Nova Odessa. Pp. 330. 